\title{
Refractory Adult Spinal Cord Neoplasm
}

National Cancer Institute

\section{Source}

National Cancer Institute. Refractory Adult Spinal Cord Neoplasm. NCI Thesaurus. Code C71715.

Spinal cord neoplasm in adulthood which is resistant to treatment. 